\title{
THE FUTURE OF INTERNATIONALIZATION OF HIGHER EDUCATION IN CHALLENGING GLOBAL CONTEXTS
}

\author{
O FUTURO DA INTERNACIONALIZAÇÃO DO ENSINO SUPERIOR \\ EM CONTEXTOS GLOBAIS DESAFIADORES
}

\section{EL FUTURO DE LA INTERNACIONALIZACIÓN DE LA EDUCACIÓN SUPERIOR EN CONTEXTOS GLOBALES DESAFIANTES}

Hans De Wit ${ }^{1}$

\begin{abstract}
Internationalization has been over the past three decades one of the key focus points of (inter)national and institutional policies for higher education, with two related components: internationalization abroad, and internationalization at home. The 'abroad' component: mobility of students, faculty and programs, has been more predominant than the 'at home' component: internationalization of the curriculum and learning outcomes, perceived as a neoliberal and western paradigm. What will be the future of internationalization? Do we see a return from competition to cooperation? What will the impact of the changing global economic, ecological and political context be? These questions will be addressed in a critical analytical way in this paper, taking into account the impact of Covid-19 on the internationalization of higher education.
\end{abstract}

KEYWORDS: Internationalization. Higher Education. University Policy. Covid-19.

\section{RESUMO}

A internacionalização tem sido, nas últimas três décadas, um dos principais focos das políticas (inter) nacionais e institucionais para o ensino superior, com dois componentes relacionados: internacionalização no exterior e internacionalização no país. O componente 'no exterior': mobilidade de estudantes, professores e programas, tem sido mais predominante do que o componente 'em casa': internacionalização do currículo e resultados da aprendizagem, percebidos como um paradigma neoliberal e ocidental. Qual será o futuro da internacionalização? Veremos um retorno da competição para a cooperação? Qual será o impacto da mudança do contexto econômico, ecológico e político global? Essas questões serão abordadas de forma analítica e crítica neste trabalho, levando em consideração o impacto da Covid-19 na internacionalização do ensino superior.

PALAVRAS-CHAVE: Internacionalização. Ensino superior. Política Universitária. Covid19.

\footnotetext{
${ }^{1}$ Doutor pela Universidade de Amsterdã. Consultoria para organizações internacionais (Parlamento Europeu e o Banco Mundial). Professor e diretor do 'Centro de Educação Superior Internacional' ( $\mathrm{CIHE}$ ) do Boston College, EUA. Membro Associado da International Association of Universities (IAU) e membro fundador e ex-presidente da European Association for International Education (EAIE). E-mail: dewitj@bc.edu
}

Submetido em: 05/05/2020 - Aceito em: 30/07/2020

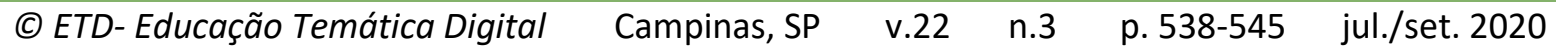




\section{RESUMEN}

La internacionalización ha sido durante las últimas tres décadas uno de los puntos clave de las políticas (inter) nacionales e institucionales para la educación superior, con dos componentes relacionados: internacionalización en el extranjero e internacionalización en casa. El componente 'en el extranjero': la movilidad de estudiantes, profesores y programas, ha sido más predominante que el componente 'en casa': la internacionalización del plan de estudios y los resultados del aprendizaje, percibidos como un paradigma neoliberal y occidental. ¿Cuál será el futuro de la internacionalización? ¿Veremos un retorno de la competición a la cooperación? ¿Cuál será el impacto del cambiante contexto económico, ecológico y político mundial? Estas preguntas se abordarán de manera analítica y crítica en este documento, teniendo en cuenta el impacto de la Covid-19 en la internacionalización de la educación superior.

PALAVRAS-CLAVE: Internacionalización. Educación Superior. Política universitaria. COVID-19.

\section{INTRODUCTION}

What now is called 'internationalization of higher education' as a concept and strategy is a phenomenon that has emerged over the last 30-40 years, driven by a dynamic combination of political, economic, socio-cultural and academic rationales and stakeholders. Many changes have happened over these past 3-4 decades and we are entering a new decade with even stronger challenges in the evolution of international dimensions in higher education around the world. This change was already happening gradually over the past decade, but has gotten a dramatic new impulse as a result of the Covid-19 crisis, affecting our planet as well as its higher education. Time for a critical reflection on the state of internationalization in higher education, in particular in the current nationalist, populist and anti-global political climate and the Covid-19 pandemic! What Knight and De Wit (2018, p. xxiii) wrote two years ago today is even more relevant than before:

As we look backwards and forwards, it is thus important to ask one question. What are the core principles and values underpinning internationalization of higher education that 10 or 20 years from now will make us look back and be proud of the track record and contribution that international higher education has made to the more interdependent world we live in, the next generation of citizens, and the bottom billion people living in poverty on our planet?

In doing so, we have to realize that the internationalization of higher education is still mainly considered in terms of a westernized, largely Anglo-Saxon, and under a predominantly English-speaking paradigm (JONES; DE WIT, 2012). Over the past decades, most scholarly and public attention with respect to internationalization in higher education has focused on the Western world. This is even more important in the current situation, as the Covid-19 crisis will impact social, economic, political and academic power relations and by that also the international dimensions in higher education around the world, and it will give bigger challenges but also more opportunities in the global south. Continental, national and institutional contexts will change and so will the impact on internationalization change in an accelerated way.

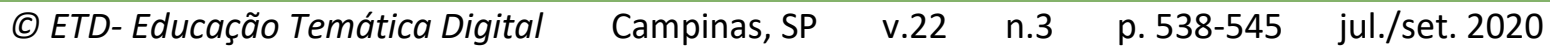




\section{FROM COOPERATION TO COMPETITION}

Internationalization must be seen in the context of the changing role and position of higher education in the world. Rapid changes are taking place in international higher education, which only have increased in range and complexity over the past decade, in particular its massification, the global knowledge economy, and the emphasis on reputation and rankings. These three key factors in higher education globally have had an important impact on its internationalization.

The emphasis on internationalization has traditionally been on exchange and cooperation and there continues to be a rhetoric around the need to understand different cultures and their languages through these two dimensions. Nevertheless, a gradual but increasingly visible shift has been apparent since the second half of the 1990's towards a more competitive internationalization.

Van der Wende (2001) calls this a shift in paradigm from cooperation to competition. Competition for students, for scholars, for talents, for the knowledge economy, for funding of complex research, for access to the top 500 in global rankings, and for access to high impact publications. Recruitment, excellence in research, and reputation are driving the agenda of institutions of higher education and national governments and their internationalization policies, at the cost of the large majority of tertiary education institutions and their students and staff, which have no perspectives to receive a high number of international students, be top research centers or be at the top of regional and global rankings (DE WIT, 2019).

According to de Wit, Hunter, Egon-Polak and Howard (2015), internationalization needs to evolve into a more comprehensive, more intentional, and less elitist (for all students and staff) process, less focused on mobility and less economically driven, with the goal to enhance the quality of education and research and make a meaningful contribution to society.

This appeal has become more predominant in a period in which nationalism, xenophobia, global political, social and economic challenges and the recent pandemic challenge heavily the role and quality of higher education and its international dimensions. 


\section{FROM AD HOC TO CENTRAL, FROM ABROAD TO AT HOME, RHETORIC OR PRACTICE?}

There is a strong call for comprehensive internationalization, which addresses all aspects of education in an integrated way. This takes, in particular, three forms. In the first place, internationalization in higher education has evolved over the past 30 years from a rather ad hoc, marginal and fragmented phenomenon to a more central and comprehensive component of higher education policy.

Secondly, while internationalization abroad or mobility is still the most dominant factor in internationalization policies worldwide, reaching only a very small percentage of students, faculty and staff, there is increasing attention being paid to internationalization of the curriculum at home.

Thirdly, although economic rationales, revenue generation, competition, reputation and rankings still drive the agenda of internationalization, there is more emphasis now being placed on other motivations for internationalization, such as quality, contribution to the Sustainable Development Goals of the United Nations, and attention to marginalized groups such as refugees (ERGIN et al., 2019), immigrants, and minorities. These three trends in themselves are positive, but they manifest themselves still more in rhetoric than in concrete action.

According to Leask, Jones and de Wit (2018), the implementation of "internationalization of the curriculum at home" appears to be struggling to move beyond good intentions and isolated examples of good practice. According to them, we are still far away from any form of internationalization that is inclusive and accessible rather than exclusive and elitist, which is the reason why they call for urgent attention to the following as a minimum:

1. We must, as scholars and practitioners, not only continue but also escalate our efforts at working together across disciplines, professional areas and national boundaries as well as within universities;

2. We must engage more with stakeholder groups beyond the academy, striving towards the common goal of creating a better, more equal and fairer world;

3. We must integrate internationalization with other agendas - disciplinary, professional, institutional, national, and regional - which are also focused on improving the quality of education and research for all students. Internationalization of the curriculum, teaching, learning and service should not operate in a vacuum;

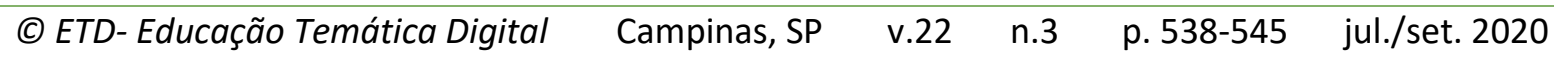


4. We must place emphasis on enhancing the quality of education and research for all students and staff in all parts of the world. This requires integrated policy and strategy as well as cooperation and partnership within and between institutions across the globe;

5. Brandenburg, Jones, Leask and de Wit (2019) call for an internationalization of higher education for society, more directed to the role of higher education in solving global problems, the Sustainable Development Goals of the United Nations.

Working towards inclusive international and intercultural learning for all means that we become more respectful of diverse contexts, agendas and perspectives on a global scale. As internationalization has moved from the margins of higher education research, policy and practice, it has become clear that the previously disjointed approaches that characterized its earliest years have given way to an understanding that sophisticated synergies are required to realize its full potential.

The updated definition of internationalization of de Wit et al. (2015, p. 29) reflects these broader understandings of the nature and purpose of internationalization:

The intentional process of integrating an international, intercultural or global dimension into the purpose, functions and delivery of post-secondary education, in order to enhance the quality of education and research for all students and staff and to make a meaningful contribution to society.

That intention to be more comprehensive and inclusive in strategies, policies and approaches to internationalization is positive, but Marinoni and de Wit (2019) observe that there is an increasing divide between institutions which consider internationalization as of high importance and those which do not. They observe that

\footnotetext{
the reasons for such a divide between HEls that consider internationalization extremely important and those which do not is worth a reflection and deserves to be studied more in depth, especially if one considers internationalization to be an essential part of all HEIs' mission and a sign of quality (MARINONI; DE WIT, 2019, p. 1).
}

The challenges that institutions encounter in their internationalization strategy are diverse. There is pressure of revenue generation, competition for talents, and branding and reputation (rankings). There is pressure to focus on international research and publication, on recruitment of international students and scholars, and on the use of English as language of research and instruction.

These challenges and pressures conflict with a more inclusive and less elitist approach to internationalization, built on the needs and opportunities of one's own students and staff. In other words, there are tensions between a short-term neoliberal approach to

(C) ETD- Educação Temática Digital Campinas, SP $\quad$ v.22 $\quad$ n.3 $\quad$ p. 538-545 jul./set. 2020


internationalization, focusing primarily on mobility and research, and a long-term comprehensive quality approach, directed at global learning for all (DE WIT, 2019).

One of the main risks is that internationalization continues to be perceived as strengthening the dominance of the existing powers in international higher education: regions, nations and institutions. The fact that only a very small elite of students, faculty and staff benefit from internationalization policies of governments and institutions implies that we are still far away from an inclusive internationalization.

\title{
4 RESPONSIBLE GLOBAL LEARNING FOR ALL
}

The main misconception about internationalization is that we consider internationalization too much as a goal in itself instead of as a means to an end. Internationalization is no more or less than a way to enhance the quality of education and research, and service to society. This quality and related internationalization as defined by De Wit et al. (2015) is under pressure, and the current global political climate (ALTBACH; DE WIT, 2017) as well as the political and economic implications of the Covid-19 pandemic are not supportive in reversing the trend, on the contrary.

De Wit and Leask (2019, p. 1) argue that,

\begin{abstract}
Aligning the practice of internationalization with human values and the common global good requires that we first challenge some of our long-held views about what it is to 'be international' as a university, a teacher, a student, a human being. This requires pushing the boundaries of our own and others' thinking, focusing on people and ensuring that they develop and demonstrate the institution's espoused human values.
\end{abstract}

Pushing the boundaries in the current political, economic and social/cultural climate which is strongly inward-looking, anti-cooperation and xenophobic, accelerated by a pandemic that in itself should strengthen the need for global cooperation but seems to enhance the opposite direction, is a major challenge for higher education and its internationalization. It will take time but mostly substantive effort to shift the pendulum into the right direction of cooperation and inclusion, to shift from a mobility focused elitist approach towards a stimulus of responsible global learning for all.

Using the opportunities of integrating online education modes instead of striving to replace onsite education by online education, bringing the world into the classroom as an alternative to excluding the large majority from the opportunity to visit the world outside the classroom, connecting the local with the global, are some of the key lessons to learn, not by words only but by collective and concrete action. That might be making us proud of our track record and the contribution of internationalization to a more inclusive and better society.

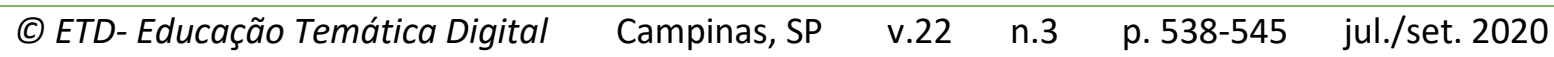


This approach, moving from perceiving internationalization as synonym to mobility for a small elite towards addressing it as an intention for global learning for all has been advocated by academics and international education professionals over the past decades. Concerns about exclusiveness, revenue generation rationales, combined with concerns of increasing nationalism and inward-looking, and concerns of sustainability and climate change were the foundation for this advocacy. The Covid-19 pandemic has made clear that these concerns are real and will endanger the future of higher education. It is to be hoped that the global crisis resulting from the pandemic will not only be seen as a challenge but also as an opportunity to change the paradigm back to cooperation and to stimulate inclusion instead of exclusion.

\section{REFERENCES}

ALTBACH, Philip G.; DE WIT, Hans. The new nationalism and internationalisation of HE. University World News, issue 474, 15 Sep. 2017.

BRANDENBURG, Uwe; DE WIT, Hans; JONES, Elspeth; LEASK, Betty. Internationalisation in higher education for society. University World News, issue 548, 20 Ap. 2019.

DE WIT, Hans. Internationalization in higher education: a critical review. SFU Educational Review, v. 12, n. 3, p. 9-17, Dec. 2019.

DE WIT, Hans; HUNTER, Fiona; HOWARD, Laura; EGRON-POLAK, Eva (Ed.). Internationalisation of higher education. European Parliament, Directorate-General for Internal Policies. Brussels, 2015.

DE WIT, Hans; LEASK, Betty. Towards new ways of becoming and being international. University World News, Number 561, 27 Jul. 2019.

ERGIN, Hakan; DE WIT, Hans; LEASK, Betty. Forced internationalization of higher education: an emerging phenomenon. International Higher Education, n. 97, p. 9-10, Spring 2019.

HUNTER, Fiona; DE WIT, Hans. The european landscape: a shifting perspective. Internationalization of Higher Education. A Handbook, Issue 2, p. 49-68, 2016.

JONES, Elspeth; DE WIT, Hans. Globalization of internationalization: thematic and regional reflections on a traditional concept. AUDEM: The International Journal of Higher Education and Democracy, n. 3, p. 35-54, 2012.

KNIGHT, Jane; DE WIT, Hans. Internationalization of higher education: where have we come from and where are we going. Preface in D. Proctor and L. E. Rumbley. The future agenda for internationalization in higher education, next generation insights into research, policy, and practice. Series Internationalization in Higher Education. London; New York: Routledge, 2018.

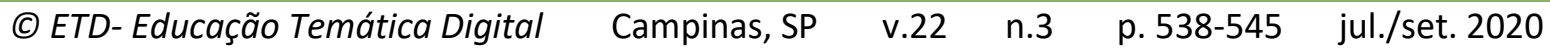


MARINONI, Giorgio; DE WIT, Hans. Internationalization and inequality, firstresults from the 5th Global Survey of IAU. University World News, Issue 534, January 2019.

PROCTOR, Douglas; RUMBLEY, Laura E. The future agenda for internationalization in higher education, next generation insights into research, policy, and practice. London; New York: Routledge, 2018.

VAN DER WENDE, Marijk. Internationalization policies: about new trends and contrasting paradigms. Higher Education Policy, n. 14, p. 249-259, 2001.

Revisão gramatical realizada por: Gabriel Brito Amorim

E-mail: gabrielbamorim@icloud.com 